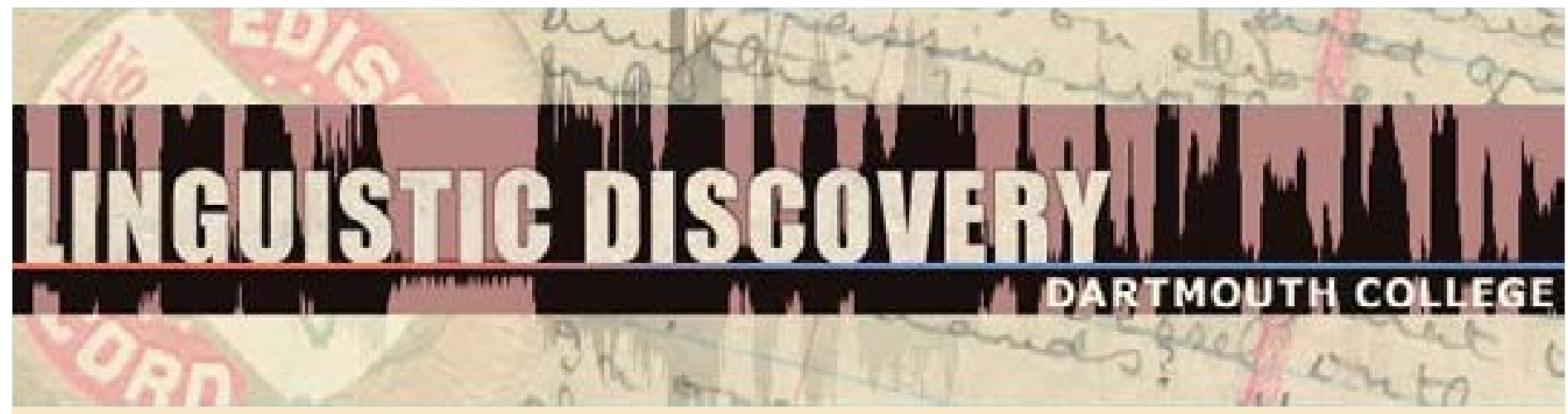

\begin{tabular}{|l|}
\hline Volume 6 \\
Issue 1 \\
2008 \\
\hline
\end{tabular}

\title{
Perfectivity and Time Reference in Hausa
}

Mahamane L. Abdoulaye

Université Abdou Moumouni

doi: $10.1349 / P S 1.1537-0852 . A .330$

url: http://journals.dartmouth.edu/cgi-bin/WebObjects/ Journals.woa/1/xmlpage/1/article/330

Linguistic Discovery

Published by the Dartmouth College Library Copyright to this article is held by the authors. ISSN 1537-0852 linguistic-discovery.dartmouth.edu 


\title{
Perfectivity and Time Reference in Hausa ${ }^{1}$
}

\author{
Mahamane L. Abdoulaye \\ Université Abdou Moumouni
}

The relative marking in Hausa marks discourse presupposition in perfective and imperfective relative clauses and out-of-focus clauses of focus and fronted wh-questions. However, the Relative Perfective also appears in storyline narrative clauses and various accounts try to find a common feature between relative clauses and narrative context. This paper rejects the common feature approach to Hausa relative marking and presents a systematic grammaticalization account of the functions of the Relative Perfective. The paper shows that in temporal when relative clauses headed by lookàcin dà 'time that', the aspectual contrast Relative Imperfective vs. Relative Perfective has vanished, and the Relative Perfective indexes the specific time of the event. The temporal relative clauses differ from locative and manner adverbial relative clauses, whose semantics (location and manner) are not usual inflectional categories and they therefore maintain the aspectual contrast between Relative Perfective and Relative Imperfective. The paper shows that the new temporal category, the Specific Time Marker, spread to other environments and incorporated a time orientation feature in main clauses of narrative and dialogical discourse to become a simple past. The paper proposes a mixed tense and aspect TAM system for Hausa, a system positioned between aspect-only and tense-prominent systems.

\section{Introduction}

In the continuum from tense and tense-prominent languages to aspect-prominent and aspect-only languages, Hausa is nowadays characterized as an aspect-prominent language where, in some accounts at least, the temporal category is not totally excluded (cf. Abdoulaye 1992:60, 1997:310n1, Jaggar 2001:154ff, 162n5, Newman 2000:564ff, and Schubert 1971/72). Earlier works however consider Hausa to be an aspect-only language (cf. Wald 1987:488), and some authors in fact explicitly exclude any kind of speech time orientation in the language by analyzing the two future paradigms as belonging to the aspect category (cf. Cowan and Schuh 1976:82ff, 122, 276, Gouffé 1966:156, 1967/68:32-36, 32n2). Crucial to these aspect-sided characterizations is the fact that a typical Hausa Completive or Imperfective main clause can receive more than one temporal interpretation. This is illustrated next:

\footnotetext{
${ }^{1}$ Hausa (Chadic) is spoken mainly in Niger and Nigeria. Primary data in this paper are mostly from Katsinanci dialect and Standard Hausa (central/east dialects). The transcription follows Hausa standard orthography with some changes. Long vowels are represented as double letters, low tone as grave accent, and falling tone as circumflex accent. High tone is unmarked. Small capital $<\mathrm{R}>$ represents an alveolar trill distinct from the flap [r]. Written $<\mathrm{f}>$ is pronounced $[\mathrm{h}]\left(\right.$ or $\left[\mathrm{h}^{\mathrm{w}}\right]$ before [a]) in Katsinanci and other western dialects. The abbreviations are: 1, 2, 3 '1st, 2nd, 3rd person'; ARP 'Aspectual Relative Perfective'; cop. 'copula'; CPL 'Completive'; DF 'definite'; F 'feminine'; FUT 'Future'; IMP 'impersonal'; IPV 'Imperfective'; M 'masculine'; NEG 'negative'; P 'plural'; RI 'Relative Imperfective'; RP 'Relative Perfective'; S 'singular'; SBJ 'Subjunctive'; SP 'Simple Past'; SSC 'scene setting clause'; STM 'Specific Time Marker', TAM 'tense/aspect/mood marker'.

This paper is part of a project on the relative marking that was supported by the University of Antwerp Research Council through a postdoctoral research position at the Center for Grammar, Cognition and Typology, University of Antwerp, 2003-2004. I thank Johan van der Auwera for his detailed comments on this paper and on various aspects of the project and for all the material support. I also extend my thanks to several reviewers for their useful comments. I am naturally solely responsible for all shortcomings.
}

Linguistic Discovery 6.1:15-39 
(1a) Lookàci-n dà su-kà daawoo, yâara sun yi kwaanaa. time-df that 3p-rp return children 3p.cpl do sleep 'At the time when they came back, the children had fallen asleep.'

$\begin{array}{llllllll}\text { (1b) Lookàci-n } & \text { dà } & \text { zaa sù } & \text { daawoo, } & \text { yâara } & \text { sun } & \text { yi kwaanaa. } \\ \text { time-df } & \text { that } & \text { fut } 3 p & \text { return } & \text { children } & 3 p . c p l & \text { do } & \text { sleep }\end{array}$ (Bime-de sleep 'By the time they come back, the children would be sleeping.'

(1c) Naa san wadànnân mutàanê-n. 1s.cpl know these people-df

'I know these people.'

(2) Ta-nàa rubùutà wàsiikàa. 3 fs-ipv write letter

'She is writing a letter/ was writing a letter/ will be writing a letter.'

In Hausa, as seen in these examples, the TAM markers are generally combined with a weak subject pronoun preceding the verb. Examples (1) show that Completive sun form (which, as we will see later, has a perfect/anterior value) can have a past interpretation, as in (1a), a future interpretation, as in (1b), and a present time interpretation, as seen in (1c) with a cognition verb. Similarly, depending on the context, the general Imperfective sentence in (2) can have a past, a present or a future interpretation. This property of tense/aspect/ mood paradigms to allow multiple temporal values is generally taken as the hallmark of aspect or aspect-dominated languages. By default, Completive and general Imperfective have, respectively, a past and present time interpretation.

However, besides Completive and general Imperfective, Hausa also uses special perfective and imperfective forms in contexts such as relative clauses, presupposed (out-of-focus) clauses of constituent focus and fronted wh-questions, and in narratives. The relative clause and the narrative use are illustrated next (cf. Jaggar 2001:526ff, 163, Newman 2000:532ff, 573):

$$
\begin{array}{lllll}
\text { kàasuwa-r } & \text { dà } & \text { Abdù } & \text { ya-kèe } & \text { zuwàa } \\
\text { market-df } & \text { that } & \text { Abdu } & 3 m s-r i & \text { going }
\end{array}
$$

'the market that Abdu visits'

$\begin{array}{lllll}\text { (3b) yâara-n } & \text { dà } & \text { su-kà } & \text { yi } & \text { kwaanaa } \\ \text { children-df } & \text { that } & 3 p-r p & \text { do } & \text { sleep }\end{array}$

'the children who slept/fell asleep'

(3c) Yâara su-kà yi kwaanaa.
children 3p-rp do sleep
'(Then) the children fell asleep.'

The relative clause in (3a) displays an alternate imperfective marker ya-kèe, which is referred to as Relative Imperfective (cf. the general Imperfective ya-nàa in (2)). Similarly, the relative clause in (3b) has the Relative Perfective marker su-kà, in contrast to Completive sun, as illustrated in (1). These alternate forms are together referred to as relative marking and they are required on the highest verb in relative and out-of-focus clauses, when these are in the perfective 
or imperfective. The Relative Perfective (but normally not the Relative Imperfective) can also be used in narrative context, as illustrated in (3c), in preference to, or to the exclusion of, the Completive. A sentence such as (3c) would typically appear in narration, i.e., with a preceding or following sequential clause. This sharing of the Relative Perfective between relative and out-offocus clauses on the one hand and narrative context on the other hand occurs in many languages displaying relative marking, besides Hausa (cf. Bearth 1993:96, Hyman and Watters 1984:259, etc.). Consequently, a number of attempts have been made to account for this phenomenon in Hausa. The common flaw in most previous accounts is the desire to explain the distribution of the relative TAM paradigms by positing some common feature uniting the various contexts. In contrast, this paper shows that in relative and out-of-focus clauses, Relative Perfective contrasts with Relative Imperfective and both are aspectual paradigms. However, in other contexts, including storyline clauses and main clauses of dialogical discourse, the Relative Perfective does not contrast with Relative Imperfective and encodes the specific time of the event (in subordinate clauses) or the simple past (in narrative and dialogical discourse). In other words, this paper claims that Hausa has three "Relative Perfectives." The first one is a "basic" perfective, with no external temporal reference (as defined for example in Comrie 1976:3). The second one is a perfective augmented with a specific time referencing function but without speech time orientation. Finally, the third one codes the simple past (i.e., the specific time of the event precedes utterance time).

Using grammaticalization theory, the aim of this paper is to retrace the development of the Simple Past from the Aspectual Relative Perfective, through the intermediary stage of the Specific Time Marker. The paper shows that the Specific Time Marker arose after the demise of the contrast between Relative Perfective and Relative Imperfective in certain contexts that include temporal relative clauses headed by lexically weak time words. The account proposed in this paper also has the overall advantage of putting Hausa in line with the results of typological and grammaticalization studies showing that in languages throughout the world, tense categories develop from aspectual categories (cf. Bybee and Dahl 1989, Lehmann 1982:31, Stassen 1997, and the vast literature on this subject). It should be noted at the outset that despite the proposed development of a simple past, this paper will not claim that Hausa is a tensed language anywhere near the standard acception of the term (cf. for example the tense criteria given in Stassen 1997:352 and references cited there).

The paper is organized as follows. Section 2 contrasts the values of Completive, Relative Perfective, and Simple Past. Section 3 retraces the development of the Specific Time Marker in temporal relative clauses and its spread in conditional clauses and in simple (non-relative) temporal clauses. Section 4 describes the use of Relative Perfective in storyline narrative main clauses. Finally, Section 5 describes the use of Relative Perfective in main clauses of dialogical discourse.

Hausa having an already established terminology sets for its tense/aspect paradigms, any further revision of the system will not fail to raise terminological issues. This paper uses the label "Completive" for the sun form, following Newman (2000:569ff). The term "relative marking" will stand as a cover term for the Relative Imperfective and Relative Perfective. The Relative Perfective encompasses the Aspectual Relative Perfective and the Temporal Relative Perfective. The Temporal Relative Perfective in turn encompasses the Specific Time Marker and the Simple Past. For easy reference, these labels are presented in Table 1. 


\begin{tabular}{|l|c|c|c|}
\hline Relative marking & \multicolumn{3}{|c|}{ Relative Perfective } \\
\hline \multirow{3}{*}{ Relative Imperfective } & $\begin{array}{c}\text { Aspectual } \\
\text { Relative Perfective }\end{array}$ & $\begin{array}{c}\text { Temporal Relative Perfective } \\
\text { Marker }\end{array}$ & Simple Past \\
\hline
\end{tabular}

Table 1: Relative marking terminology

In Table 1, the four terminal tense/aspect paradigms are Relative Imperfective, Aspectual Relative Perfective, Specific Time Marker, and Simple Past. As is usual in general linguistics literature, tense/aspect labels written with capital initials refer to language-specific categories (the standard ones found in previous Hausa literature as well as the new ones proposed in this paper).

\section{The contrast perfect vs. perfective in Hausa}

The sun-form paradigm, the tense/aspect category referred to in Hausa literature as the (general) "Completive" (or Perfective, accompli I, etc.) has actually been compared to the English perfect (past, present, or future, cf. Newman 2000:569ff; cf. also Caron 1991:164ff and Schubert 1971/72:220f). Indeed, the Completive can express functions typically expressed by perfect categories in other languages (cf. Comrie 1976:56-61, Dahl 1985:129ff for the uses of the perfect). In this respect, the Completive contrasts with the Aspectual Relative Perfective (i.e., the Relative Perfective used in relative and out-of-focus clauses) and contrasts even more with the Simple Past (i.e., the Relative Perfective used in narrative and dialogical main clauses). For example, only Completive allows an anterior reading, as illustrated in the following:

(4a) Sun zoo karfèe biyu.

3P.CPL come o'clock 2

'They came at 2 o'clock.' OR 'By 2 o'clock they have arrived.'

(4b) Karfèe biyu sun zoo.

o'clock 2 3P.CPL come

'By 2 o'clock they have arrived.' NOT: 'They came at 2 o'clock.'

(4c) Sun zoo.

3P.CPL come

'They have arrived.' OR 'They came [and went back].

In (4a), the Completive allows an anterior reading (second interpretation), where the coming event happened before 2 o'clock. One notices the sentence also allows a perfective-like interpretation (first interpretation), where the coming event happened at exactly 2 o'clock, and which is actually the default interpretation of the sentence. However, this is not a sure indication that the Completive is a real perfective since, as shown in Dahl (1985:137), many languages differ from English in allowing their perfect tense/aspect paradigm to co-occur with definite time adverbs. In fact, when the time adverb is preposed in a topicalized-like construction, then only the anterior reading is possible, as indicated in (4b). Similarly, without a time specification, as illustrated in (4c), the Completive can be interpreted as a perfect of result with a current relevance value. For example, $(4 \mathrm{c})$ is the most straightforward way to alert someone that some 
people have arrived so that he/she can go see them. In contrast, Aspectual Relative Perfective and Simple Past cannot express the anterior meaning, as illustrated next:

Karfèe biyu (nèe) su-kà zoo.

o'clock 2 cop. 3P-ARP come

'It is at 2 o'clock that they came.' NOT 'It is by 2 o'clock that they have arrived.

(5b) Suu (nèe) su-kà zoo karfèe biyu.

3P cop. 3P-ARP come o'clock 2

'It is them who came at 2 o'clock.' NOT 'It is them who have arrived by 2 o'clock.'

(5c) Su-kà zoo karfèe biyu.

3P-SP come o'clock 2

'(then) they came at 2 o'clock.' NOT 'By 2 o'clock they have arrived.'

Sentences (5a-b) illustrate the Aspectual Relative Perfective in focus-fronting constructions, focusing the temporal adverb and the subject, respectively. This tense/aspect paradigm does not allow the anterior reading, as indicated. Similarly, sentence (5c) shows that Simple Past does not express anterior sense, as indicated.

Other types of perfect meanings seem to be possible both with the Completive and the Aspectual Relative Perfective, but not with the Simple Past (for various uses of the perfect, cf. Comrie 1976:60 and the reference cited there). This seems to be case with the ability of the tense/aspect paradigms to appear in experiential perfect context, as illustrated next:

Sun ta6à zuwàa Gaanà.
3P.CPL touch going Ghana
'They have once traveled to Ghana.'

(6b) Suu (nèe) su-kà tabà zuwàa Gaanà. 3P cop. 3P-ARP touch going Ghana 'It is them who once traveled to Ghana.'

(6c) *Su-kà tabà zuwàa Gaanà. 3P-SP touch going Ghana

'(Then) they once traveled to Ghana.'

As the data show, Completive and Aspectual Relative Perfective are compatible with the experiential context, as indicated in (6a-b) respectively, in contrast to Simple Past, as indicated in (6c).

In conclusion, the sun-form is a perfect category in Hausa. The Aspectual Relative Perfective that appears in relative and out-of-focus clauses can be considered a true perfective, since it does not have key perfect readings, such as the perfect of result. This paper will consider the Aspectual Relative Perfective as a "basic" perfective, that is, the perfective as defined in Comrie (1976:3f), which is an aspectual category that presents a situation as a single unanalyzable whole, i.e., without reference to its internal temporal structure. The perfective essentially differs from the perfect (or anterior) in having no relevance to a reference time, usually the present situation. The Simple Past is even more remote from the perfect semantics, since it cannot express or is not compatible with any of the perfect meanings reviewed in this section. There are 
a few reasons why one may label the narrative Relative Perfective as a "Simple Past." First, the term Simple Past is preferable because it is general and familiar in the linguistic literature. It is indeed less restricted than terms like "definite perfective," "historical aspect," "sequential marker," and "aorist," a term which, according to Bearth (1986:297n136), is sometimes used in African linguistics to designate an aspect specialized in narratives. In fact, as will be shown in this paper, the Simple Past is not restricted to narratives and can appear in main clauses of dialogical contexts. Secondly, the term Simple Past is more indicative of the progressive development that has probably taken place, and is better than terms such as "past perfective" or "perfective past" or even simply "perfective," as when this category is taken to inherently incorporate a reference to past time (cf. Bybee and Dahl 1989:83, Dahl 1985:78f). Indeed, this paper will suggest that in Hausa, the Simple Past developed step-wise, as shown in the following diagram:

\section{(7) Aspectual Relative Perfective $=>$ Specific Time Marker $=>$ Simple Past}

In this diagram, only the first category is aspectual since it contrasts with the Relative Imperfective. The other two categories, Specific Time Marker and Simple Past, display temporal features and do not contrast with the Relative Imperfective in their contexts, as respectively shown in the next two sections. The next section looks at the shift from Aspectual Relative Perfective to Specific Time Marker.

\section{From aspectual relative perfective to specific time marker}

It may be remembered that in relative, constituent focus, and fronted wh-question or wh-ever constructions, Relative Perfective and Relative Imperfective fully contrast and both are obligatory in their function of marking the presupposed clauses of these constructions. Nonetheless, there are some particular contexts where the information contained in a relative clause has some saliency. In these cases, the clause reverts to Completive and general Imperfective. This is illustrated next (sentence (16c) adapted from Beik 1987:122):

(8a) mùtunè-n [dà koo yaa mutù koo

man-DF that whether 3MS.CPL die or

ya-nàa dà râi àllaahù wa'àlam]

3MS-have life only God knows

'the man [who only God knows whether he is dead or alive]'

(8b) Kanòo, BiRnii wandà dâa maa ya-nàa dà mahimmancìi à Hausa Kano city which in any case 3MS-have importance in Hausa 'Kano, a city which in any case has a great significance in Hausaland'

(8c) Àkwai wata wàd-dà mun sâa ta, ta-nàa yîi, mun ganii exist another one-that 1P.CPL put 3FS 3FS-IPV do 1P.CPL realize baa tà iyà tà yi. NEG.IPV 3FS be.able 3FS.SBJ do 'There is one [woman] whom we tried, she was trying, we realized that she could not.' 
In (8a) the relative clause carries information that is marked as uncertain with the conjunction koo 'whether'. As can be seen, the two embedded clauses carry the Completive and the general Imperfective. The relative tense/aspect paradigms would be ungrammatical in this context. One way to account for this is to say that the marked uncertainty of the information takes the relative clause out of the presupposition domain and both Relative Perfective and Relative Imperfective, as markers of presupposition, are cancelled. Data (8b) illustrate a non-restrictive relative construction (cf. Jaggar 1998:220ff, Schubert 1971/72:283), where in general the relative clause contains additional secondary information about the head. Since the clause is not presupposed, the general Imperfective can be used, as indicated. More generally, it has been established in Hausa that relative constructions containing some modal or adverbial particles manipulating the relative clause information may take Completive and general Imperfective (cf. Jaggar 1998:214ff, 2001:531n6, 537f). Finally, in (8c) the story is framed in a relative clause construction and the speaker chooses to use the non-relative tense/aspect paradigms since he is giving new information about a referent, and not just identifying it (which is the normal function of relative clauses).

In contrast, this section deals with temporal when relative clauses where the Relative Imperfective freely alternates with general Imperfective, while the Relative Perfective is obligatorily maintained. The claim will be that in this context, the relative marking as an aspectual contrast is lost, but that the Relative Perfective survived because it has acquired a new function. The section also discusses conditional/temporal in/ìdan clauses and temporal (nonrelative) dà clauses where only Relative Perfective appears. In all these environments, the Relative Perfective is not the presupposition marker but the exponent of a temporal category, the Specific Time Marker (which is glossed "STM" in the illustrations).

\subsection{Demise of relative marking in temporal lookàcin dà 'when' relative clauses}

Most Hausa grammars note that in temporal relative clauses headed by lookàcii 'time' (or its equivalent sa'àa/ saa'ìdii/ sàa'ilii) the relative marking is optional (cf. Abraham 1959:163, who gives san dà sunàa yâaraa = san dà sukèe yâaraa 'during their boyhood', lit. 'time that they were kids'; cf. also Jaggar 2001:531). However, this is true only to some extent, and the situation is not simple, as illustrated next:

$\begin{array}{llllll}\text { Naa } & \text { san } & \text { lookàci-n } & \text { dà } & \text { ya-kèe/ *ya-nàa } & \text { kwaanaa. } \\ \text { 1S.CPL } & \text { know } & \text { time-DF } & \text { that } & 3 \mathrm{MS}-\mathrm{RI} / 3 \mathrm{MS}-\mathrm{IPV} & \text { sleep }\end{array}$

'I know the time when he sleeps.'

$\begin{array}{llllll}\text { Sun } & \text { zoo } & \text { lookàci-n } & \text { dà } & \text { ya-kèe/ ya-nàa } & \text { kwaanaa. } \\ \text { 3P.CPL } & \text { come } & \text { time-DF } & \text { that } & \text { 3MS-RI/ 3MS-IPV } & \text { sleep }\end{array}$

'They came while he was sleeping.'

$\begin{array}{llllll}\text { Naa } & \text { san } & \text { lookàci-n } & \text { dà } & \text { su-kà/*sun } & \text { fita. } \\ \text { 1S.CPL } & \text { know } & \text { time-DF } & \text { that } & \text { 3P-STM/ 3P.CPL } & \text { go.out }\end{array}$

'I know the time they went out.'

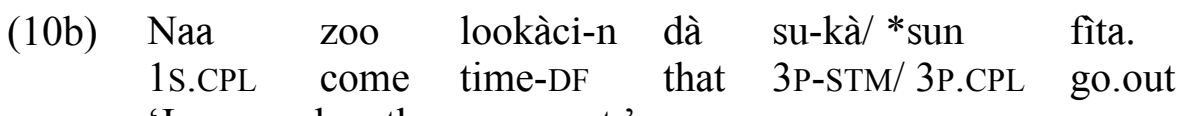
'I came when they were out.' 
The examples in (9) both illustrate the Imperfective. When the word lookàcii 'time' functions as a true referential head to the relative clause, Relative Imperfective is required, as shown in (9a). However, if lookàcii is a weak head (i.e., not referential) and the relative clause functions as a grammaticalized temporal adverbial clause, then the Relative Imperfective freely alternates with general Imperfective, as indicated in (9b). By contrast, examples (10) show that the Relative Perfective is required in a relative clause headed by a referential noun lookàcii, as in (10a), or in a temporal adverbial clause, as seen in (10b). One may interpret the facts illustrated in (9-10) as showing the collapse of the relative marking as an aspectual contrast in temporal relative clauses, whether they are in the perfective or imperfective. Therefore, the Relative Perfective seen in (10b) is maintained because it has acquired a new function, i.e., the indexation of a specific time for the event in the adverbial clause.

It is very likely that the perfective semantics of the Aspectual Relative Perfective in relative clauses has favored the new function. Indeed, the perfective is already temporally restricted. Internally, the perfective event is presented rolled-up in a punctual perspective, i.e., with no reference to the event's temporal structure (cf. Comrie 1976:3). Externally, the perfective event has no connection with the present (no current relevance). One may assume that in temporal adverbial relative clauses, the Relative Perfective has picked up a time referencing function and grammatically indexes the external time point (or time stretch) when the event happened. On this account, it can be considered a temporal category, the Specific Time Marker, even though it doesn't yet have a speech time orientation. Indeed, while the Specific Time Marker in (10b) has a past interpretation, other temporal relative clauses can receive (present/past) habitual or future interpretations. This is illustrated next (data (11a) adapted from Moussa-Aghali 2000:5):

(11a) Lookàci-n dà gòorùbâ-n nan su-kà yi diyaa... time-DF that palmtrees-DF there 3P-STM do fruits 'Whenever those palmtrees have fruits (people would harvest them...)'

\begin{tabular}{|c|c|c|c|c|c|c|c|}
\hline $\begin{array}{l}\text { Lookàci-n } \\
\text { time-DF }\end{array}$ & $\begin{array}{l}\text { dà } \\
\text { that }\end{array}$ & $\begin{array}{l}\text { su-kà } \\
\text { 3P-STM }\end{array}$ & $\begin{array}{l}\text { Kaarèe, } \\
\text { finish }\end{array}$ & $\begin{array}{l}\text { kù } \\
2 p . S B J\end{array}$ & $\begin{array}{l}\text { biyaa } \\
\text { pay }\end{array}$ & $\begin{array}{l}\text { sù } \\
3 \mathrm{P}\end{array}$ & $\begin{array}{l}\text { kudi-n-sù. } \\
\text { money-of-3P }\end{array}$ \\
\hline
\end{tabular}

Example (11a) is part of a narrative text describing a village living on palmtrees and the event described in the temporal clause is cyclical or habitual. In sentence (11b), the time reference of both subordinate and main clause events is clearly the future. In all these sentences however, the Specific Time Marker encodes the specific time of the event. This paper hence distinguishes the Aspectual Relative Perfective (in relative and out-of-focus clauses) from the temporal Specific Time Marker.

There is one indication that the demise of the relative marking in temporal relative clauses is due to the headword lookàcii 'time' (and at least one of its equivalents). Indeed, besides temporal circumstances, place and manner circumstances also are expressed through grammaticalized adverbial relative clauses. However, since place and manner are not usual features of verbal inflection, they have no bearing on the relative marking. Consequently, place and manner adverbial relative clauses fully maintain the aspectual contrast between Aspectual Relative Perfective and Relative Imperfective, as seen in the following: 
$\begin{array}{lllllll}\text { (12a) } & \begin{array}{l}\text { Sun } \\ \text { 3P.CPL }\end{array} & \text { kai } & \text { saanìyaa } & \text { in-dà } & \text { a-kèe/ *a-nàa } & \text { wà } \\ & \text { cow } & \text { there-that } & \text { IMP-RI/IMP-IPV } & \text { to }\end{array}$

dabboobii àlluuRàa.

animals vaccination

'They took the cow where animals are vaccinated.'

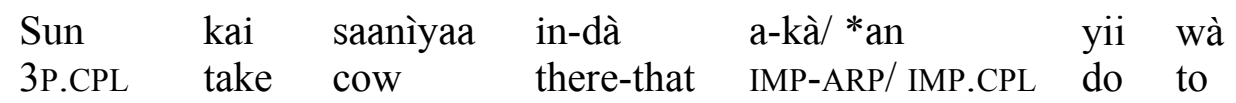

dabboobii àlluuRàa.

animals vaccination

'They took the cow where animals were vaccinated.'

$\begin{array}{lllllll}\text { Su-nàa } & \text { yî-n } & \text { koomii } & \text { yad-dà } & \text { a-kèe/*a-nàa } & \text { nuunàa } & \text { ma-sù. } \\ \text { 3P-IPV } & \text { Doing-of } & \text { everything } & \text { like-that } & \text { IMP-RI/IMP-IPV } & \text { show } & \text { to-3P }\end{array}$

'They are doing everything as one shows them how to do.'

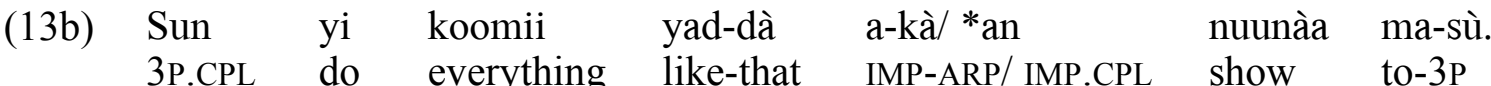

'They did everything as one showed them how to do.'

Examples (12a-b) illustrate a locative adverbial clause in the imperfective and perfective respectively, while examples (13a-b) similarly illustrate a manner adverbial clause. As can be seen, in all cases the relative marking is obligatory, as shown by the ungrammaticality of general Imperfective and Completive. Normally, locative and manner clauses such as illustrated in (12-13) are taken to be relative clauses introduced by the subordinator dà preceded by weak heads, locative particle in- and manner particle ya-, respectively (cf. Jaggar 2001:530f and Newman 2000:535). While none of these particles is a typical nominal, locative particle inclearly relates to locative demonstrative în/inniya 'there' and interrogative inaa 'where', while manner ya- relates to comparative conjunction yà/iyaa (as in yaaròo yà Abdù 'a boy like Abdu') and interrogative yàayàa 'how'. The locative in- has, as a less general alternative, the regular noun wurii 'place' (as in sun zoo wurin dà akèe wà dabboobii àlluuRàa 'they came to the place where animals are vaccinated'), which also requires the aspectual relative marking. To summarize, the demise of the relative marking observed in temporal relative clauses is not solely due to their adverbial function but also to their temporal function.

Nonetheless, there are indications that the degree of grammaticalization of the temporal clause is also important. Indeed, the word lookàcii 'time' has some alternatives, but only one of them, sa'àa 'hour, time, occurrence' (or saa'ìdii 'time, moment'), is apparently general enough to cause the demise of the relative marking. Some of these alternative words are illustrated next:

(14a) Sun jee haR Lòme sa'àd-dà su-kèe/ su-nàa neeman Abdù. 3P.CPL go till Lome time-that 3P-RI/3P-IPV search Abdu 'They went up to Lome while searching for Abdu.' 


$$
\begin{array}{llllll}
\text { Naa } & \text { ganee } & \text { sù } & \text { sa'àd-dà } & \text { su-kà/*sun } & \text { fitoo. } \\
\text { 1S.CPL } & \text { see } & \text { 3P } & \text { time-that } & \text { 3P-ARP/ 3P.CPL } & \text { come.out }
\end{array}
$$

'I saw them as they came out.'

$$
\begin{array}{lllll}
\text { Ran-dà } & \text { a-kèe/ *a-nàa } & \text { neema-n-su } & \text { baa su } & \text { gànuwaa. } \\
\text { Day-that } & \text { IMP-RI/ IMP-IPV } & \text { searching-of-3P } & \text { NEG.IPV 3P } & \begin{array}{l}
\text { be.seen } \\
\text { 'When one is looking for them (i.e., when one needs them), one cannot see them.' }
\end{array}
\end{array}
$$

$\begin{array}{lllllll}\text { Ran-dà } & \text { a-kà/ *an } & \text { nèemee } & \text { sù } & \text { kàasuwaa } & \text { su-kà } & \text { tàfi. } \\ \text { day-that } & \text { IMP-ARP/ IMP.CPL } & \text { search } & 3 \mathrm{P} & \text { market } & \text { 3P-ARP } & \text { go }\end{array}$

'(On the day) when one looked for them, they were at the market.'

As the translations indicate, the relative clauses in (14-15) are functionally temporal adverbial clauses. Nonetheless, they behave differently with respect to the integrity of the relative marking. While sa'àd-dà 'time that' behaves like lookàcin dà in allowing the breakdown, ran-dà 'day/time that' fully requires the relative marking.

To summarize, in temporal relative clauses where the head has a certain degree of generality, the aspectual contrast between Relative Imperfective and Relative Perfective can be eliminated. In this context, the Relative Perfective survives by taking up the new function of indexing the specific time at which the event takes place, whether this time is past, cyclical, or future. Very likely, the perfective's inherent features favored the change, as well as the fact that time semantics can in general be incorporated into verbal inflection. A more explicit case of such incorporation happens in metrical tense languages. For example, Diki-Kidiri (1988:118ff) shows that Sango (pidgin, Ubangian) has time adverbials that can also function as tense markers in a developing metrical tense system. Similarly, Marchese (1984:192ff, 199) presents correspondences in Kru languages between time adverbials (such as "today, yesterday, day before yesterday, tomorrow, etc.") and related affixes grammaticalized to metrical tense markers (see Binnick 1976:206 on metrical tense languages). More generally, Anderson (1973:42), as discussed in Fleischman (1983:198, 208n35), proposes that time adverbials are the source of tense, which can be conceived of as a concord on the verb referring to the temporal adverbs. Maybe a similar relation can be posited between the time words lookàcii or sa'àa and the Specific Time Marker. Hausa differs from metrical tense languages in that an inferred general meaning "specific time" was incorporated, rather than some particular temporal adverb (such as "yesterday"). In addition, in Hausa, an aspectual marker was re-interpreted for the new temporal function, instead of a new tense marker developing and combining with the aspect marker.

\subsection{Relative Perfective in conditional or temporal in/ìdan clauses}

Hausa has a conjunction in/ìdan that introduces reality conditional clauses and temporal clauses, as illustrated next:

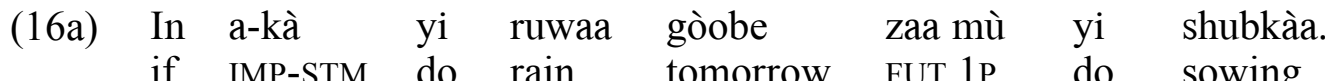
'If it rains tomorrow we will do some sowing.' 


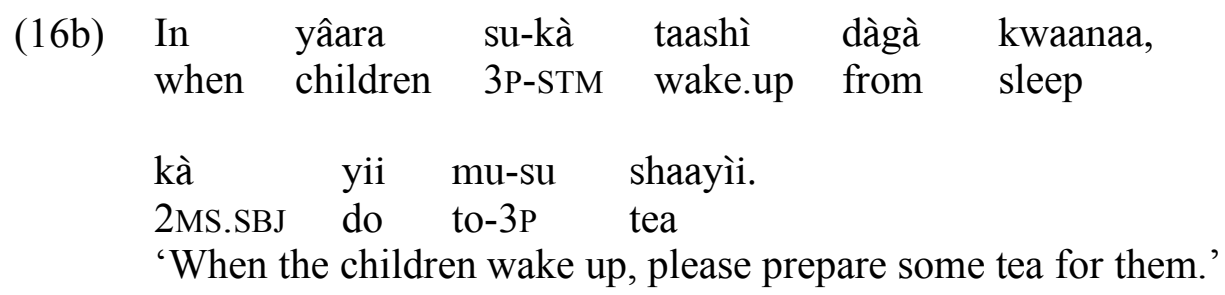

Sentence (16a), under normal circumstances, is interpreted as a typical hypothetical conditional construction, where the atmospheric event of the rain falling is not certain to happen. In (16b) on the other hand, the context makes it clear that the event in the in/idan clause is certain to happen. In fact, this clause can be replaced with a plain temporal clause with the same meaning (cf. lookàci-n dà yâara su-kà taashì.. 'when the children wake up...'). As can be noted, in both examples the Relative Perfective can be used.

Although in/ìdan clauses accept many tense/aspect paradigms (including Completive, general Imperfective, the two futures, etc.), they do not accept the Relative Imperfective. For example, in no context at all is the following clause grammatical: *idan sukèe wàasaa 'if they are playing', and the general Imperfective must be used (cf. ìdan sunàa wàasaa 'if they are playing'). For this reason, this paper assumes that in/ìdan clauses are an environment of expansion for the temporal Relative Perfective in its new function as Specific Time Marker. The new function is evidenced when one contrasts Completive and Specific Time Marker, as illustrated next (cf. also Abdoulaye 1992:69ff, 1997:310n1):

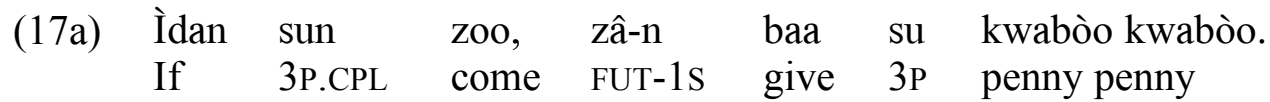

'If they come, I will give them a penny each.' (uncertain, wait and see)

'When they come [from school], I will give them a penny each.' (certain)

'If it turns out they have come, I will give them a penny each' (uncertain, check)

(17b) Ìdan su-kà zoo, zâ-n baa sù kwabòo kwabòo. if 3P-STM come FUT-1s give 3P penny penny

'If they come, I will then give them a penny each.' (uncertain, wait and see)

'When they come [from school], I will then give them a penny each.' (certain)

NOT: 'If it turns out they have come, I will then give them a penny each' (uncertain, check)

The first noticeable difference between the two sentences is the fact that the Completive conditional clause in (17a) can have a potential one-time past event reading, due to the current relevance value of the Completive. Otherwise, with both tense/aspects, in/idan particle can have a conditional (uncertain) or a temporal (certain) value. The difference between similar senses of (17a) and (17b) has to do with the temporal proximity between the events in the protasis and the apodosis. Sentence (17a) says nothing about this temporal proximity, i.e., it is only known that the event in the apodosis will follow the event in the protasis. In sentence (17b) on the other hand, the reward (giving pennies) is understood to immediately follow the children's arrival, hence the presence of the adverbial then in the translations (cf. Wald 1987:495f for a similar function associated with the Swahili tense marker $1 i-$ ). For this reason, one may take the Relative Perfective in (17b) to be the Specific Time Marker. 
The apodosis context specified in (17b) favors a one-time future event reading of the Specific Time Marker. However, Specific Time Marker in in/ìdan clauses can also have a recurrent past event interpretation or a present habitual interpretation, as illustrated next:

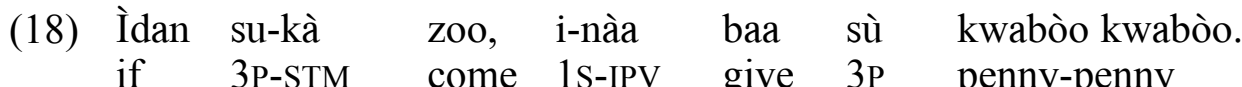

'When they come, I usually give them a penny each/ I used to give them a penny each.'

Although sentence (18) implies many instances of the two events, the Specific Time Marker still marks a temporal proximity between each event of coming and the ensuing event of giving a penny. For this reason, one may consider that the Specific Time Marker can mark the specific time of both single-occurrence or recurrent events.

To summarize, the Relative Perfective in in/idan conditional or temporal clauses is the Specific Time Marker. In these clauses, the Specific Time Marker has no past time reference per se, since it can refer to past and future events, just as it does in temporal lookàcin dà relative clauses. Contrary to temporal lookàcin dà clauses, the in/ìdan clauses do not at all accept the Relative Imperfective. One may take this as a sign that the Specific Time Marker spread into environments where originally there was no relative marking contrast.

\subsection{Relative Perfective in simple temporal dà clauses}

Most descriptions of Hausa temporal clauses claim or assume that temporal relative clauses, especially the ones headed by the word lookàcii 'time', can derive simple temporal clauses introduced by the subordinator dà only. The derivation would involve deletion of the word lookàcii 'time' (cf. Bagari 1976/87:117, Jaggar 2001:624, Newman 2000:556, Tuller 1986:113ff, Watters 2000:223). In fact, for most authors (cf. Jaggar 2001:624, 629), lookàcii temporal relative clauses derive a whole series of temporal clauses introduced by phrasal subordinators involving the particle dà, such as: (lookàcin) dà '(time) when', sai (lookàcin) dà 'till (time) when', tun (lookàcin) dà 'since (time) when', etc. This section shows that there is no direct derivation between temporal lookàcin dà clauses and simple temporal dà clauses (cf. also Abdoulaye 1992:65f, 77n6). The section concludes that simple temporal dà clauses are a spreading environment for the Specific Time Marker, where it also has a strict past interpretation.

The claim that temporal lookàcin dà relative clauses are the source of simple temporal dà clauses is usually based on examples where the word lookàcii 'time' seems optional, as illustrated next (cf. also Bagari 1976/87:117, Watters 2000:223):

(19a) (Lookàci-n) dà su-kà zoo, sai mu-kà ci àbinci. time-DF that 3P-STM come then 1P-STM eat food

'When they arrived, we ate.'

(19b) Yâara sun ga sarkii (lookàci-n) dà su-kà shìga gàrii. Children 3MS.CPL see emir time-DF that 3P-STM enter town 'The children saw the emir when they entered (i.e., visited) the town.'

'The children saw the emir when they were entering the town.' 
In examples (19), presence or absence of the word lookàcii 'time' seems to make no difference in the meaning of the sentence. Even ambiguous readings, as illustrated in (19b), can obtain irrespective of the presence of the word lookàcii. This derivation in fact is thought to be a more general process. For example, Wald (1987:509n5) notes that West African languages commonly use a relative subordinator also as a temporal clause subordinator (cf. also Reineke 1998:103). Though some simple dà clauses may be so derived, there are however at least two good indications against a wholesale derivation of simple temporal dà clauses from temporal lookàcin dà relative clauses through deletion of the head lookàcii.

The first indication in favor of underived temporal dà clauses is the fact that assuming such underived clauses would allow one to link them with other temporal expressions also using the particle dà. Some of these expressions are illustrated next (sentence (21a) adapted from MoussaAghali 2000:8):

(20a) Ciiwòn nân yaa zoo dà dàamanaa. Sickness this 3MS.CPL come DA rainy.season

'This sickness came with the rainy season (i.e., at the beginning of the season).'

'This sickness came during the rainy season.'

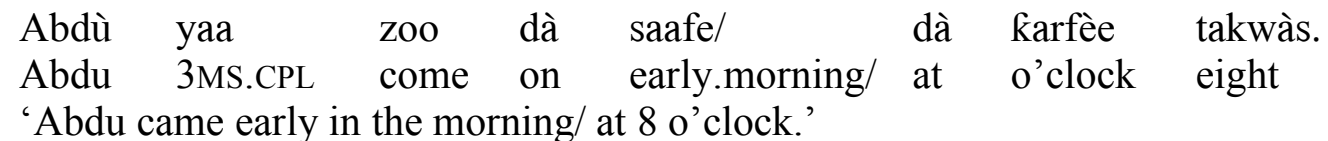

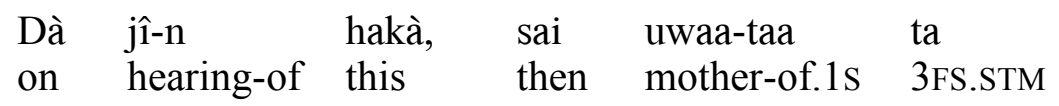

buushèe dà dàariyaa.

blow with laughter

'On hearing this, my mother laughed.'

(21b) Dà ta ji hakà, sai uwaa-taa ta

when 3FS.STM hear this then mother-of.1s 3FS.STM

buushèe dà dàariyaa.

Blow with laughter

'When she heard this, my mother laughed.'

As suggested in Abdoulaye (2004:167ff, 2006:1123ff), particle dà probably originated as an existential predicate (cf. dà ruwaa 'there is water'). This existential predicate gave rise through grammaticalization to a comitative particle (cf. yaa zoo dà Bàlki 'he came with Balki'; cf. Heine and Reh 1984:58, 62 on the development of comitative particles from "be included" predicates in Ewe and Yoruba). The comitative marker would in turn give rise to the nominal coordinating conjunction 'and' (cf. Abdù dà Bàlki sun zoo 'Abdu and Balki came') and probably the instrumental dà (cf. yaa yankà naamàa dà wukaa 'he cut the meat with a knife'). Given data (20-21), one can hypothesize that comitative dà probably also gave rive to temporal subordinator dà. Sentence (20a) is ambiguous between a comitative and a temporal reading and can be taken as one of the intermediary contexts inducing the change. Sentence (20b) gives some temporal adverbs (times of day, clock time) introduced by dà. Finally, in (21a), dà introduces a verbal noun and the construction is equivalent to a finite temporal dà clause, as indicated in (21b). The 
alternation in (21) between a preposition and a conjunction is a feature of many particles in Hausa (cf. sai Abdù 'only Abdu (can do something)' and sai kaa jee can 'only [if] you go there (can you achieve something)', etc.). Examples (20-21) clearly establish temporal usages of dà that are unrelated to lookàcin dà relative clauses.

The second indication in favor of underived simple dà clauses relates to the possible tense/aspect paradigms and their temporal interpretation in the two temporal clauses. Lookàcin dà relative clauses appear with six paradigms: Specific Time Marker, general Imperfective or Relative Imperfective, Future I, Habitual, and Eventual. Except for the Habitual, all paradigms can receive, depending on the context, a past or a future interpretation, as already illustrated in (10-11) for the Specific Time Marker (cf. also the Future I lookàcin dà zaa su tàfi 'when they were/will be leaving'). In contrast, simple temporal dà clauses allow only four tense/aspect paradigms, Completive, Relative Perfective, general Imperfective, and Future I. The temporal interpretations of these paradigms are presented in Table 2.

\begin{tabular}{|l|l|l|l|l|}
\hline \multirow{2}{*}{} & \multicolumn{2}{|l|}{ Past reference } & \multicolumn{2}{l|}{ Future reference } \\
\cline { 2 - 5 } & One-time & Recurrent & One-time & Recurrent \\
\hline Completive: dà sun tàfi & & Yes & Yes & Yes \\
\hline Relative Perfective: dà sukà tàfi & Yes & & & \\
\hline Imperfective: dà sunàa tàfiyàa & Yes & Yes & & \\
\hline Future I: dà zaa sù tàfi & Yes & & & \\
\hline
\end{tabular}

Table 2: Temporal interpretations in simple temporal dà clauses (with tàfi 'leave, go')

For three of the four tense/aspect paradigms occurring in simple dà clauses in Table 2, one can observe a certain anchoring of the temporal interpretation in the past. Only Completive accepts a future reading. Even Future I in this context describes a "future-in-the-past," i.e., the event in the main clause precedes, and sometimes cancels, the event in the temporal clause, with both events in the past (cf. dà zaa sù tàfi, sai ta rufè Koofà- $R$ "when they were about to leave, she locked the door'). A probable reason for the anchoring to the past observed in Table 2 may be the influence of the ultimate origin of dà clauses, i.e., existential/comitative dà-constructions, which would tend to describe realized situations. No matter the correct explanation, the past time anchoring is certainly incompatible with a lookàcii deletion analysis. It is also clear that the difference in temporal interpretation guarantees that temporal relative clauses and simple temporal dà clauses will not have the same uses (cf. for example, *(lookàcin) dà yâara sukà taashì kà yii musù shaayii 'when the children wake up, please prepare some tea for them', where the weak head cannot be deleted).

Having established the existence of underived temporal dà clauses, one can now characterize the Relative Perfective that appears there. This paper proposes that the Relative Perfective in temporal dà clauses such as illustrated in (21b) is the Specific Time Marker, which here has a strict past interpretation (cf. Table 3). Indeed, simple temporal dà clauses contrast with similarlooking dà clauses that function as background to their main clauses and where the relative marking (including Relative Imperfective) is a presupposition marker. The contrast is illustrated next:

(22a) [Dà su-kèe tsòoro-n à kaamàa su $]$ sun gudù.

As 3P-RI fear-of IMP.SBJ arrest 3P 3P.CPL flee

'[As it is the case they are afraid of being arrested], they fled.'

(background reading)

(No temporal reading available) 


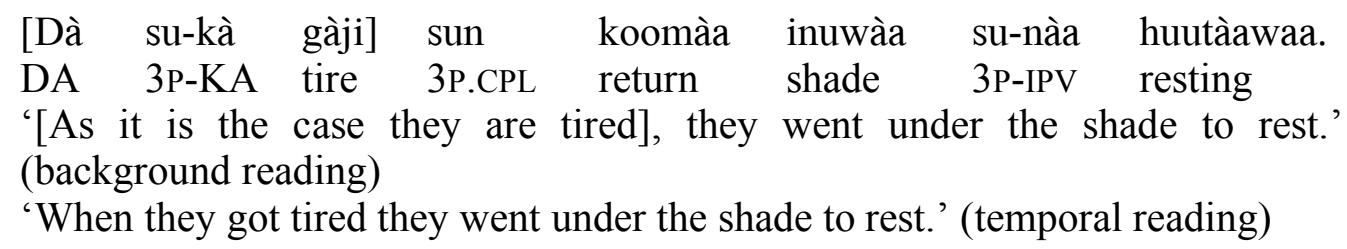

Sentence (22a) contains a reason adverbial dà clause (in brackets) with Relative Imperfective and it can only be interpreted as a scene-setting clause (SSC), i.e., a clause that supplies the background context in which the main clause event takes place and whose content is typically known by the hearer (cf. Abdoulaye 1997). To get the temporal reading, general Imperfective must be used (cf. dà sunàa tsòoron à kaamàa su... 'when they were afraid of being arrested...', with the past-anchored interpretation). As shown in (22b), a dà clause with Relative Perfective is ambiguous between a SSC reading and a (past-anchored) temporal reading. This sentence clearly evidences at least two types of Relative Perfective in Hausa. One Relative Perfective (Aspectual Relative Perfective) contrasts with Relative Imperfective and marks presupposition in SSCs, relative clauses, and out-of-focus clauses. The other Relative Perfective (Specific Time Marker) does not contrast with Relative Imperfective and marks specific time. Since temporal dà clauses do not accept Relative Imperfective, one can assume that they constitute a spreading context for the Specific Time Marker.

In conclusion, this section has shown that the Relative Perfective found in canonical relative clauses and in out-of-focus clauses is different from the Relative Perfective found in temporal relative clauses, in/îdan conditional clauses, and simple temporal dà clauses. The former contexts have a purely aspectual category, the Aspectual Relative Perfective, while the later contexts have a category intermediary between tense and aspect, the Specific Time Marker. Indeed, this category codes the specific (external) time of the event but without speech time orientation.

\section{Relative Perfective in storyline narrative main clauses}

A sequence can be defined as a series of at least two events that are temporally ordered (Event 1 + Event 2) and where, typically, a preceding event defines the reference time for the following event (cf. Andersen 1994:256, discussing Lulubo; Dahl 1985:112, and Tuller 1986:98, discussing Hausa). When the sequence is made up of independent main clauses expressing single-occurrence events cast in the past, then one is dealing with a typical narrative sequence (for the criteria of a canonical narrative discourse, cf. Adam 1994:92-105 and Wald 1987:483ff, 506, who cites Labov and Waletzsky 1967). This section essentially argues that the Relative Perfective used in storyline clauses is not a special kind of narrative marker (i.e., consecutive/sequential marker, narrative tense, aorist, etc.) but a simple past referring to a specific time. For this reason, the Relative Perfective in this section is glossed "SP" (for Simple Past) in relevant examples.

As observed in numerous Hausa studies (cf. Caron 1991:171f, Jaggar 2001:162, Newman 2000:572, etc.), the Relative Perfective is the narrative TAM par excellence. Indeed, it is the TAM that appears (to the exclusion of almost all other TAMs) in main clauses that constitute the narrative storyline. One may note however that other tense/aspect paradigms do appear in sequential main clauses, but such sequences may not answer the definition of a canonical narrative (cf. in particular Tuller 1986:95ff for Hausa sequential constructions in general). For example, there is a minimal contrast between Completive and Simple Past in a sequential construction, as illustrated in the following: 


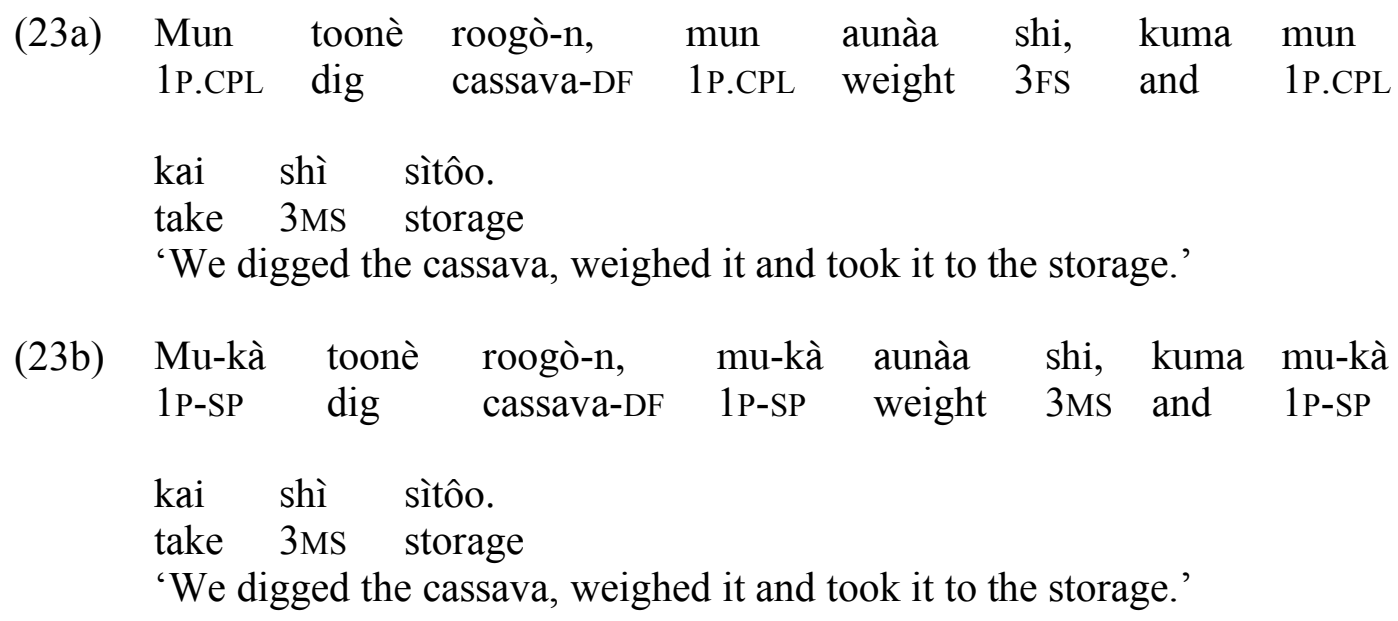

The examples in (23a-b) describe the same events and are equally interpreted as sequential, past, and single-occurrence. Nonetheless, they are used in different circumstances. Sentence (23a) in Hausa would be used in reporting a series of actions to someone entitled to receive such a report, a supervisor for example. It will be told with the expectation that the receiver would acknowledge what happened, take some action, etc. This usage probably results from the current relevance value of the Completive. The clauses in (23a) do not seem to be necessarily connected and indeed the apparent ordering of events is not important (i.e., the report could be like a checklist of the activities done, which will be individually appreciated by the supervisor). Indeed, that a (narrative-style) event ordering and connectedness are not significant, even for a naturally ordered sentence such as (23a), is shown by the fact that the sequential particle sai 'then' cannot be used in the sentence. In contrast, sentence (23b) would be used to tell a story just for that purpose, say, to a friend. Here the events are reported detached from the present and resolutely cast in the past, each at a specific time. The time specificity is reflected by the fact that the sequential particle sai 'then' can be used before any of the clauses (even the first one).

Another TAM frequently associated with event sequences is the Subjunctive. Besides its normal irrealis functions (to express wishes, orders, etc.; cf. Jaggar 2001:184), the Subjunctive in Hausa is also used to mark sequential clauses, with the first clause generally having a TAM other than the Subjunctive, in a consecutive-marking structure (cf. Tuller 1986:95ff; cf. also the discussion of data (25) below). With past events, Subjunctive sequential clauses obligatorily receive a habitual sequence interpretation, while Relative Perfective clauses, typically at least, describe single-occurrence events. However, this may not be the only difference between the Subjunctive and the Relative Perfective. Indeed, there are indications that one important difference relates to the fact that the Relative Perfective must refer to a specific action, contrary to the subjunctive. This is illustrated in the following (example (24a), taken from a Cinderella story, is adapted from INDRAP 1983a:59): 


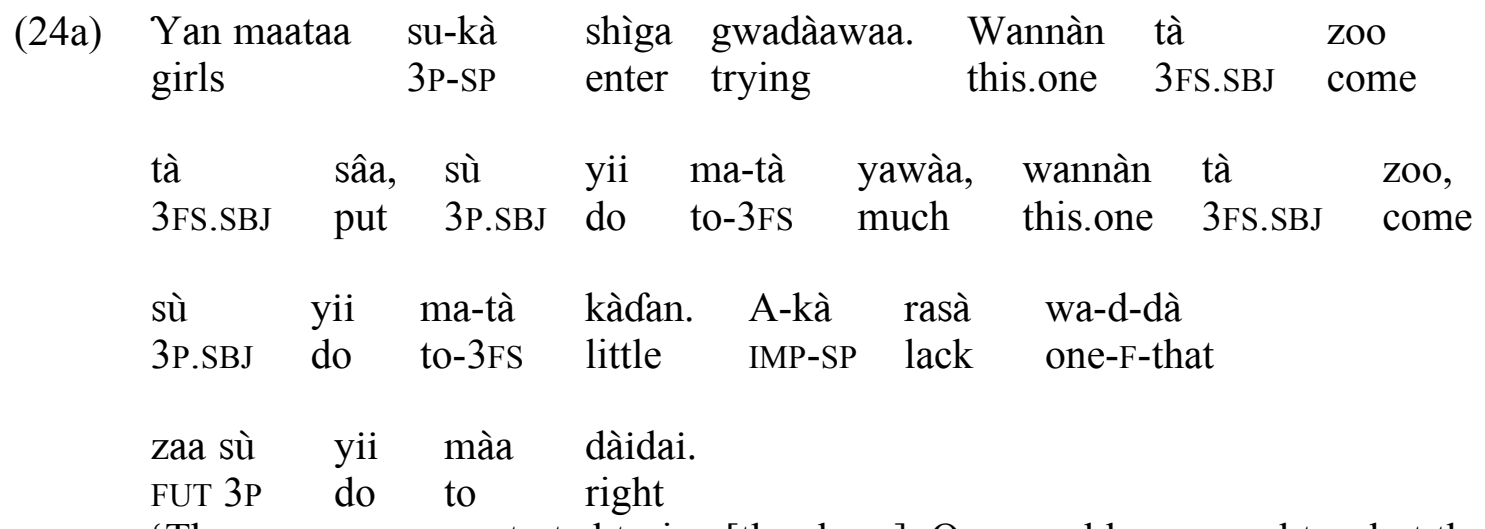

'The young women started trying [the shoes]. One would come and try, but they [the shoes] would be too big, another would come [and try] and they would be too little. None of them fit the shoes.'

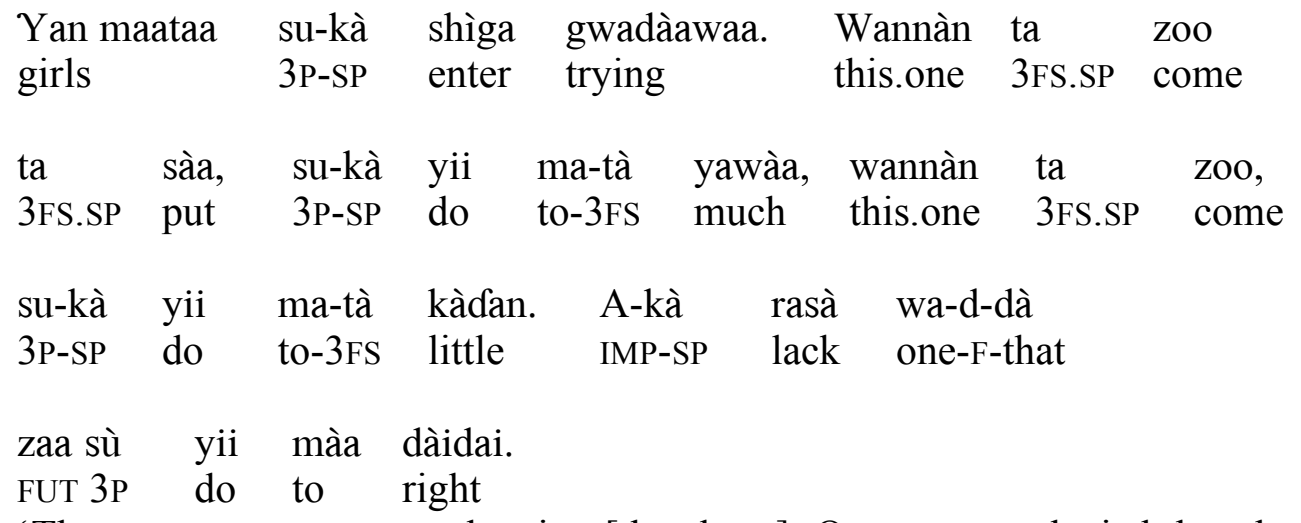

'The young women started trying [the shoes]. One came and tried, but they [the shoes] were too big, another one came [and tried] and they were too little. None of them fit the shoes.'

The second sentence in examples (24a-b) embeds two sequences ('a woman coming, trying the shoes that are too big' and 'a woman coming, trying the shoes that are too small') that are understood to be recurrent in (24a) but single-occurrence in (24b). But there is another difference that relates to the specificity of the clause subject. In example (24a), the singular demonstrative pronouns do not refer to two specific women repeatedly trying the shoes. In fact, the demonstrative pronouns refer to all young women (of the town) who tried the shoes. That is, although the events in the second sentence of (24a) are formally presented as individualized (cf. the singular demonstrative pronouns), the actions themselves, due to their Subjunctive TAM, are unspecific. By contrast, in (24b), with the Relative Perfective, the events are necessarily interpreted as specific (only two women tried the shoes). It should be noted that the Subjunctive allows both a specific and an unspecific reading of a subject (cf. sai mùtun yà zoo yà sàaci àbinkàa which can be interpreted as unspecific past habitual 'one (various people on different occasions) would come and steal your property' or specific past habitual 'a (particular/same) person would repeatedly come and steal your property').

Despite the sequential readings of (23b-c) and (24b), in narrative main clauses, too, there are many indications showing that the Relative Perfective - or any other TAM for that matter -- is not in fact a sequential (or consecutive) marker. First, in genuine consecutive-marking 
constructions, the first (or sometimes the last) clause of the chain does not bear the sequential marker (cf. Wald 1987, Carlson 1987:1 on Sùpyìré (Gur); and Longacre 1990 for an extensive study of consecutive-marking constructions in African languages). In Hausa narrative main clauses, the Relative Perfective can appear in all clauses of the sequence, including the first clause, as seen in the following (adapted from INDRAP 1983b:44):

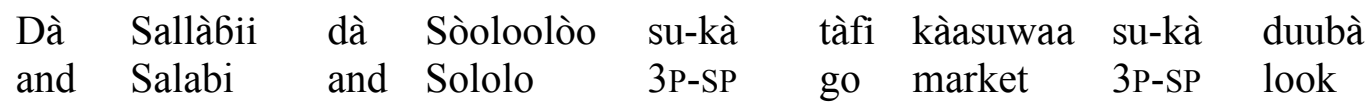

ràagoo su-kà sayoo.

ram 3P-SP buy

'Salabi and Sololo went to the market, looked for a ram and bought one.'

Sentence (25), with three sequential clauses in Simple Past, is the very first sentence of its story. In fact, the volume containing the story has sixteen independent stories and eight of them start off with a Simple Past clause. A narrative, by definition, reports a series of temporally sequenced events, generally in the past (cf. Wald 1987:506). However, when in a section of a story, it is necessary to report main events that are not sequential in the real world, one notices that the Simple Past can still be used, as is illustrated next:

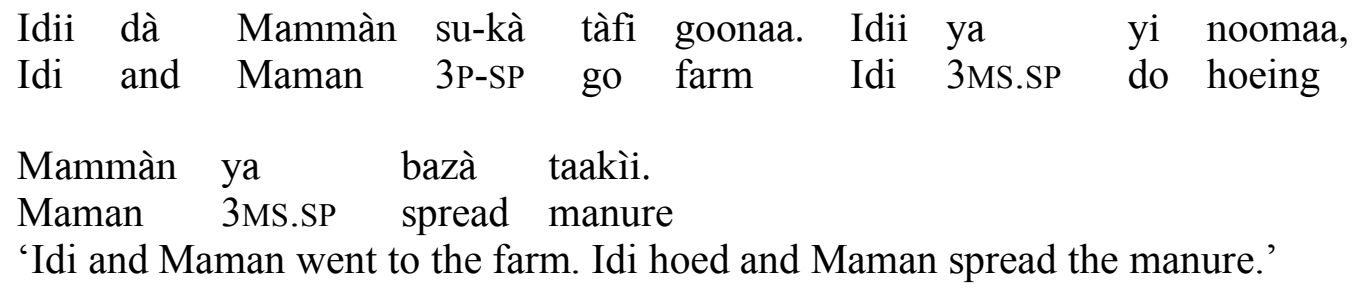

All clauses in (26) contain the Simple Past, yet some of the events are understood as simultaneous. This shows that sequential interpretation depends on real world knowledge and is not an inherent function of a particular tense/aspect paradigm (cf. Bres 2003:100 for a discussion of the relations between sequentiality and French Passé Simple).

It should also be noted that the time specificity coded by the Specific Time Marker or Simple Past cannot be equated with the notion of single-occurrence or punctuality of events. As seen in the discussion of (18), clauses with Specific Time Marker can express multiple-occurrence events. In the case of (18) for example, there is time specificity for each pair of coming and giving pennies. Similarly, the specific time referred to may be that of the inception of an event, the end of an event, both beginning and end, or the entire external timeline implicated in an durative or multiple-occurrence event (cf. Bres 2003:103 for a discussion of these properties with French Passé Simple). Some of these points are illustrated next:

(27a) Su-kà rikà sayaR dà mootoocî-n. A cikin saatii su-kà 3P-SP keep selling cars-DF in week 3P-SP

$\begin{array}{lll}\text { sayaR dà } & \text { mootoocii } & \text { goomà. } \\ \text { sell } & \text { cars } & \text { ten }\end{array}$

'They kept selling the cars. In a week they sold ten cars.' 
(27b)

\begin{tabular}{|c|c|c|c|c|c|c|}
\hline $\begin{array}{l}\text { Ya } \\
3 \mathrm{MS} . S P\end{array}$ & $\begin{array}{l}\text { àuri } \\
\text { marry }\end{array}$ & $\begin{array}{l}\text { ya-R } \\
\text { daughter-of }\end{array}$ & $\begin{array}{l}\text { Saulaawaa } \\
\text { Saulawa }\end{array}$ & $\begin{array}{l}\text { su-k } \\
3 \mathrm{P}-\mathrm{s}\end{array}$ & $\begin{array}{l}\text { sàamu } \\
\text { get }\end{array}$ & $\begin{array}{l}\text { diyaa } \\
\text { children }\end{array}$ \\
\hline & $\begin{array}{l}\text { diyâ-n } \\
\text { children-DF }\end{array}$ & $\begin{array}{ll}\text { su-kà } & \text { girma, } \\
\text { 3P-SP } & \text { grow.up }\end{array}$ & $\begin{array}{l}\text { sànnan } \\
\text { then }\end{array}$ & $\begin{array}{l}\text { su-kà } \\
3 \mathrm{P}-\mathrm{SP}\end{array}$ & $\begin{array}{l}\text { koomàa } \\
\text { return }\end{array}$ & $\begin{array}{l}\text { Saafòo. } \\
\text { Safo }\end{array}$ \\
\hline
\end{tabular}

In sentence (27a), the event of selling the cars happened repeatedly in both clauses. In the first clause, the coded specific time is the entire timeline associated with the events. The amount of that time is actually given in the second clause (two weeks). In the first clause of (27b), the coded time point is that coinciding with the beginning of the event. The second clause probably refers to the entire time during which the three kids were born. In the third and fourth clauses, the coded times are probably the times coinciding, respectively, with the end-point and the beginning of the event.

In the literature, based on translations of narratives, the narrative Relative Perfective has been likened to English Preterit (cf. Jaggar 2001:162) or French Passé Simple (cf. Abdoulaye 1992:63). However, since storyline events in a narrative are typically interpreted as past, one in principle may not automatically assign an inherent speech time orientation to a storyline tense/aspect paradigm. That is, for Hausa, the narrative Relative Perfective can just as well be considered as the Specific Time Marker (cf. Section 3), which will automatically get a speech time orientation from the narrative context. Nonetheless, for Hausa there is another motivation for taking the narrative Relative Perfective as the Simple Past. Indeed, in main clauses of dialogical discourse, where there is no contextual restriction to past events, the Relative Perfective still cannot be used to refer to non-past events and must hence be considered to have an inherent time orientation. Furthermore, taking narrative Relative Perfective as a Simple Past would allow one to characterize Hausa assertive main clauses with a special tense/aspect system, as opposed to subordinate and non-assertive clauses, as the next section shows.

\section{Relative Perfective in main clauses of dialogical discourse}

The use of Relative Perfective in main clauses of dialogical discourse has not been investigated or explicitly taken into account in previous studies. One may take dialogical discourse to be centered on the speech situation. In this context, the speaker, in order to achieve his/her goals, can refer to past individual events with or without current relevance, to past narratives, to the future, and to various realms of possibilities. Typically, dialogical discourse would take place between individuals in a direct communication. This section focuses on the use of Relative Perfective in main clauses of dialogical discourse and shows that in this context, it has probably incorporated an obligatory past time reference feature and, on this account, can be labeled as Simple Past (cf. discussion at end of the section). We will therefore see that the specific time feature of Simple Past and the current relevance value of Completive explain the differences between sets of sentences that minimally differ by their tense/aspect paradigms. An illustration of these TAMs in dialogues is given next: 


$\begin{array}{lllll}\text { (28a) HaR yànzu bà sù } & \text { taashì } & \text { ba? } \\ \text { till now NEG.CPL 3P } & \text { wake.up } & \text { NEG } \\ \text { 'They are still sleeping?' } & & \end{array}$

(28b) Dà saafe sun taashì haR su-kà karyàa. on morning 3P.CPL rise even 3P-SP breakfast 'Earlier in the morning they did wake up and even had breakfast.'

(28c) Dà saafe sun taashì (*haR) sun karyàa. On morning 3P.CPL rise even 3P.CPL breakfast 'Earlier in the morning they woke up and had breakfast.'

In the context of (28a), the speaker of (28b), with Simple Past in the second clause, uses the breakfast event as evidence to support the reality of the waking up, hence the use of haR 'even, till, already'. The Simple Past in the sentence codes a specific time (time of waking up) for the event in the second clause. The two events are presented as closely connected temporally and the whole sentence is rooted in the past without connection to the present. In contrast, the purpose of sentence (28c), with Completive in both clauses, is to report the two events and the connecting particle haR 'even' cannot be used, as indicated (i.e., one event is not used as evidence for the other). Similarly, a sentence such as sun zoo sukà koomàa 'they came but/and returned', with Simple Past in the second clause, may imply that the visitors went back so quickly that they achieved nothing during the visit. A Completive in the second clause, as in sun zoo sun koomàa 'they came and returned', has no emphasis on the temporal connectedness of the events and implies, by default, that the visitors achieved the aim of their visit. The connectedness effect can also be seen in the following:

Bàakii su-kà tàfi bà kà shâidaa ma-nì ba!

Guests 3P-SP go NEG.CPL 2MS notify to-1S NEG

'How come the guests left and you did not tell me [and I missed greeting them].'

$\begin{array}{lllllll}\text { Bàakii } & \text { sun } & \text { tàfi } & \text { bà kà } & \text { shâidaa } & \text { ma-nì } & \text { ba! } \\ \text { guests } & \text { 3P.CPL } & \text { go } & \text { NEG.CPL 2MS } & \text { notify } & \text { to-1s } & \text { NEG }\end{array}$

'How come the guests are no longer around and you did not advise me.'

By uttering (29a), the speaker is regretting the fact he/she did not learn about the departure before it happened. Again, the situation is rooted in the past and there are no current consequences from the past events. The speaker of sentence (29b), in contrast, complains about not having been informed after the situation has changed. Normally, such sentence is uttered when there are current consequences of the failure to notify about the departure. One may note that negative Perfective has no special relative form. Therefore, since there is no grammatical contrast specific time vs. non-specific time, negative Perfective can appear in either context, as seen more clearly next:

(30a) Dà faatan bà kù mâncee ku-kà rufè koofàa ba. 'I hope that you did not forget (the instructions) and (mistakenly) locked the door.' 
(30b) Dà faatan bà kù mâncee kun rufè koofàa ba. With wish NEG.CPL 2P forget 2P.CPL lock door NEG 'I hope that you haven't forgotten and have (indeed) locked the door.'

Sentence (30a) has Simple Past in the second clause and the speaker hopes that the door was left open. In sentence (30b), with Completive in the second clause, the speaker hopes that the door was closed. One way to account for this contrast is to assume that in (30a), both events (forgetting and locking the door) are time-specific and temporally connected, and that the sentence is translatable as 'I hope you did not then forget (the instructions) and then (mistakenly) locked the door'. In contrast, in (30b) the two events have no specific time and in particular, the state of not forgetting was enduring. Notice that the contrast Simple Past vs. Completive can show its effects even in monoclausal sentences that are independent of a preceding or a following linguistic context. This is illustrated next:

(31a) Wadànnan àbùkkâ-n naa-kà su-kà zìyàRcee mù ran sallàa. Those friends-DF that.of-2MS 3P-SP visit 1P day.of festival 'Those friends of yours (were so nice and) visited us during the festival.'

(31b) Wadànnan àbùkkâ-n naa-kà sun zìyàrcee mù ran sallàa. those friends-DF that.of-2MS 3P.CPL visit 2P day.of festival '(Be advised that) those friends of yours have visited us during the festival.'

Sentence (31a), with Simple Past, matter-of-factly informs the listener of the visit. The sentence is totally disconnected from the present and the speaker expects nothing more to follow. In particular, there is no need of a related exchange preceding or following the sentence (i.e., the situation is evoked "in passing," the friends or their visit not being the subject of a long discussion). Sentence (31b), with Completive, advises the listener of the visit, as an acknowledgement or information for the listener's usage: the listener may be pleased or act in any way appropriate towards the friends. This is why the sentence can be followed by comments such as yaa kàmaatà kai maa kà zìyàRci ìyàllansù 'you, too, should visit their families', whereas such a consequence-related comment would be unnatural with (31a). Another indication that (31a) purely serves information purposes is the fact that it cannot be re-told under any circumstances, whereas (31b) can be re-told to remind hearer he did not draw all the consequences after the previous communication.

Doubtless, there are many more semantic and pragmatic implications of the contrast between Completive and Simple Past and the few illustrations given cannot be exhaustive. In most of these illustrations, the contrast between the two tense/aspects was explained by the current relevance of the Completive vs. the time specificity of the Simple Past. One may then wonder whether the Relative Perfective found in dialogical discourse is not simply the Specific Time Marker described in Section 3. However, it happens that the Relative Perfective in main clauses of dialogical discourse has a strict past time reference, as seen in all examples given in the section. It cannot be used in main clauses to refer to non-past events, contrary to most other tense/aspect paradigms.

To summarize, Hausa seems to have grammaticalized in two steps two temporal features in its perfective TAM, the Relative Perfective. These features are the specific time of the event and the speech time orientation. Nonetheless, as illustrated in the introductory section, Hausa has the characteristics of an aspect-dominated language and speech time orientation is definitely not an obligatory feature in the language. How can one then reconcile this situation with the existence 
of a Simple Past? The existence of a Simple Past in an aspect-dominated language like Hausa can be understood in the framework of grammaticalization theory. In particular, the proposal of a Simple Past in Hausa is consistent with the body of literature dealing with the development of simple past tenses in world languages. For example, Bybee and Dahl $(1989: 58,74)$ show that in a number of languages (including Romance languages, Mandarin, Somali, Palaung, etc.) a perfect has taken over the functions of a perfective or a past tense. Stassen (1997) on the other hand assumes a more general tendency for aspect or aspect-dominated languages to shift over some period towards tense marking (cf. Stassen 1997:492,563). What is also significant is that in shifting from aspect to tense dominance, languages may pass through a transitional or mixed tense and aspect encoding stages, where it is not clear what the dominant category is (Stassen 1997:480 cites some Bantu languages as being in this situation). Hausa is apparently entering the transitional stage and one may propose the TAM system portrayed in (32), a system that is split along the line subordinate or non-assertive clauses vs. assertive main clauses:

(32a) Subordinate and non-assertive clauses

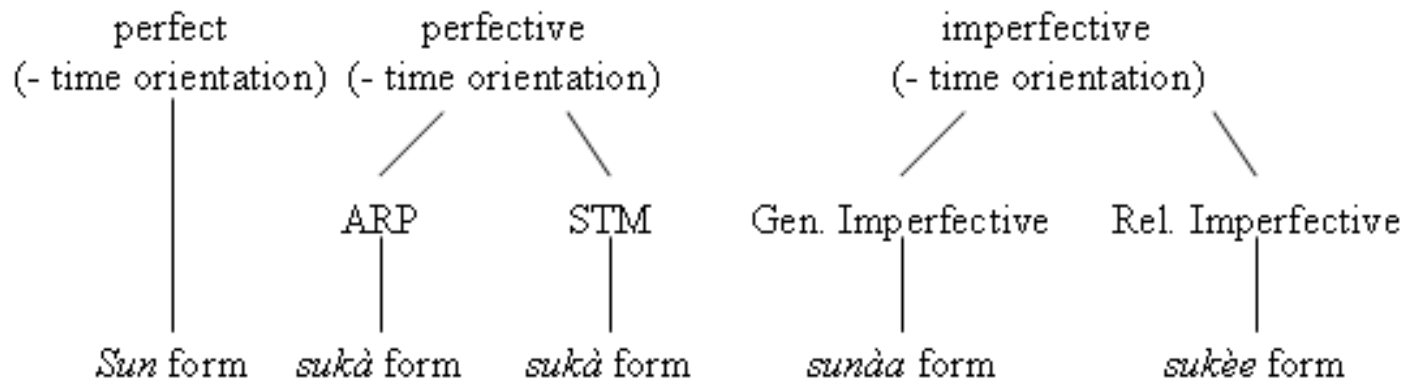

(32b) Assertive main clauses (narrative and dialogical discourse)
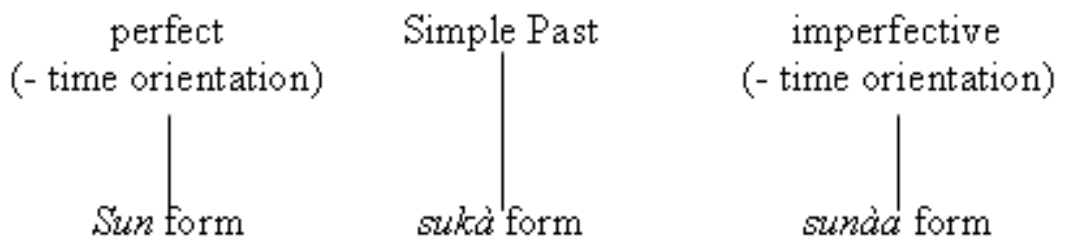

The context of (32a) is in fact more unitary than it appears. The term "subordinate" there refers to relative clauses and temporal and conditional clauses, as discussed in the paper. The term "non-assertive clauses" refers to the out-of-focus clauses. These have been analyzed as subordinate clauses (cf. Caron 1991:21, 159, 171 and Parsons 1960:19). However, Abdoulaye (2007) proposes that out-of-focus clauses are former subordinate clauses that are now reanalyzed as main clauses, although they are non-assertive main clauses. Therefore, in some sense, the context in (32a) can simply be referred to as the subordinate context. One notices that the subordinate context is aspectual, with no speech time orientation (at least with respect to the TAM paradigms portrayed). The context (32b) refers to main clauses of narrative and dialogical discourse and displays a simpler TAM system. In this mixed tense and aspect system, a former perfective TAM has acquired specific time reference and speech time orientation and is labeled "Simple Past." This way is consistent with grammaticalization tendencies by which, once a new 
meaning is incorporated into a form, it may later become the most prominent or even the only available meaning in the reanalyzed form (cf. for example the development of future tenses from motion verbs). Therefore, in (32b) the Simple Past is fundamentally a temporal -- not an aspectual -- category, even though it may have inherited perfective features (event viewed in a rolled-up manner without current relevance).

However, it is also clear from (32b) that Hausa tense, as a grammatical category, is rather limited, since there is no time orientation in the imperfective. Hausa is therefore unlike some West-African languages with a generic past marker (cf. for example Fula) or with metrical tense markers that periphrastically or morphologically combine with aspect markers (cf. discussion at the end of Section 3.1). All these remarks considered, one must conclude that Hausa is an aspectdominated language with a tense category that is not combinable with aspect categories. ${ }^{2}$

\section{Conclusion}

The relative marking (Relative Imperfective and Relative Perfective) in Hausa canonically appears in scene setting clauses, relative clauses, and out-of-focus clauses of constituent focus and fronted wh-questions or wh-ever constructions. Hausa however, also uses Relative Perfective in narrative and dialogical contexts. Contrary to earlier accounts, this paper analyzes the Relative Perfective in main clauses of narratives and dialogical discourse as the Simple Past. The Simple Past differs from the Relative Perfective found in presupposition contexts, which is aspectual and contrasts with Relative Imperfective. The paper shows that one of the contexts for the genesis of Simple Past is the temporal lookàcin dà relative clause. In this clause, the semantics "specific time" was incorporated into the Relative Perfective, which then became a specific time marker, and the aspectual contrast Relative Imperfective vs. Relative Perfective was eliminated. From this initial environment, the paper shows that the new specific time category spread to environments that originally did not have the relative marking contrast, environments such as in/îdan temporal or conditional clauses, simple temporal dà clauses, and finally the narrative and dialogical discourse, where it acquired speech time orientation. These proposals are congruent with the results of typological and grammaticalization studies, which show that in languages throughout the world, aspect markers diachronically derive tense markers.

\section{References}

Abdoulaye, Mahamane L. 1992. Aspects of Hausa morphosyntax in Role and Reference Grammar. Unpublished Ph.D. dissertation. The University at Buffalo.

-----. 1997. Presupposition and realis status in Hausa. Sprachtypologie und Universalien Forschung 50.308-328.

-----. 2004. Comitative, coordinating, and inclusory constructions in Hausa. Coordinating constructions, ed. by Martin Haspelmath, 165-193. Amsterdam: John Benjamins.

-----. 2006. Existential and possessive predications in Hausa. Linguistics 44.1121-1164.

-----. 2007. Profiling and identification in Hausa. Journal of Pragmatics 39.232-269.

Abraham, Roy Clive. 1959. The language of the Hausa people. London: London University Press.

Adam, Jean-Michel. 1994. Le texte narratif: Traité d'analyse pragmatique et textuelle. Paris: Nathan.

\footnotetext{
${ }^{2}$ Use of Relative Imperfective, the sukèe form, in main clauses of dialogical discourse is attested, even if the conditions of such use are still unclear. For some examples see Abdoulaye (1992.77n6).
} 
Andersen, Torben. 1994. From aspect to tense in Lulubo: Morphosyntactic and semantic restructuring in a Central Sudanic language. Tense, aspect and action: Empirical and theoretical contributions to language typology, ed. by Carl Bache, Hans Basbøll and CarlErik Lindberg, 235-263. Berlin/New York: Mouton.

Anderson, J. 1973. An essay concerning aspect. The Hague: Mouton.

Bagari, Dauda Muhammad. 1976/87. Hausa subordinate adverbial clauses: Syntax and semantics. Rabat: Imprimerie El Maarif Al Jedida. (1976 Ph.D. dissertation, UCLA).

Bearth, Thomas. 1986. L'articulation du temps et de l'aspect dans le discours toura. Sciences Pour La Communication Series. Berne/Franckfort Sur-Le-Main: Peter Lang.

-----. 1993. Satztyp und Situation in einigen Sprachen Westafrikas. Afrikanistentag, ed. by Brauner Möhlig and Herrmann Jungraithmayr, 91-104. Köln: Rüdiger Köppe.

Beik, Janet. 1987. Hausa theatre in Niger: A contemporary oral art. Garland: New York/London.

Binnick, Robert. 1976. How aspect languages get tense. CLS, Papers from the Parasession on Diachronic Syntax.

Bres, Jacques. 2003. Non, le passé simple ne contient pas l'instruction [+progression]. Modes de repérages temporels, ed. by Sylvie Mellet and Marcel Vuillaume, 99-112. Amsterdam/New York: Editions Rodopi B.V.

Bybee, Joan L. and Östen Dahl. 1989. The creation of tense and aspect systems in the languages of the world. Studies in Language 13.51-103.

Carlson, Robert. 1987. Narrative connectives in Sùpyìré. Coherence and grounding in discourse: Outcome of a symposium, Eugene, Oregon, June 1984, ed. by Russell S. Tomlin, 1-19. Amsterdam: John Benjamins.

Caron, Bernard. 1991. Le haoussa de l'Ader. Berlin: Dietrich Reimer.

Comrie, Bernard. 1976. Aspect. Cambridge: Cambridge University Press.

Cowan, J. Ronayne and Russell G. Schuh. 1976. Spoken Hausa. Ithaca, NY: Spoken Language Services, Inc.

Dahl, Östen. 1985. Tense and aspect systems. Oxford: Basil Blackwell.

Diki-Kidiri, Marcel. 1988. Aspects, modes et temps en sango. Temps et aspects: Actes du Colloque CNRS, Paris 24-26 October, 1985, ed. by Nicole Tersis and Alain Kihm, 117-124. Paris: Peeters/SELAF.

Fleischman, Suzanne. 1983. From pragmatics to grammar: Diachronic reflections on complex pasts and futures in Romance. Lingua 60.183-214.

Gouffé, Claude. 1966. Les problèmes de l'aspect en haoussa. I: Introduction. Le problème de l'aoriste et de l'accompli II. Comptes-rendus du Groupe Linguistique d'Etudes ChamitoSémitiques (GLECS) 10.151-165.

-----. 1967/68. Les problèmes de l'aspect en haoussa III: L'inaccompli négatif et l'ingressif. Comptes-rendus du groupe linguistique d'études chamito-sémitiques (GLECS) 12.27-51.

Heine, Bernd and Mechthild Reh. 1984. Grammaticalization and reanalysis in African languages. Hamburg: Helmut Buske.

Hyman, Larry M. and John R. Watters. 1984. Auxiliary focus. Studies in African Linguistics 15.233-273.

INDRAP, Government of the Republic of Niger. 1983a. Ja Dare [Leader of the night]. Vol. 1. Niamey: INDRAP.

----. 1983b. Ja Dare [Leader of the night]. Vol. 3. Niamey: INDRAP.

Jaggar, Philip J. 1998. Restrictive vs non-restrictive relative clauses in Hausa: Where morphosyntax and semantics meet. Studies in African Linguistics 27.199-238.

----. 2001. Hausa. Amsterdam: John Benjamins. 
Labov, William and J. Waletsky. 1967. Narrative analysis: Oral versions of personal experience. Essays in the verbal and visual arts, ed. by June Helm, 12-44. Seattle: University of Washington Press.

Lehmann, Christian. 1982. Thoughts on grammaticalization: A programmatic sketch. Vol. 1. Cologne: University of Cologne.

Longacre, Robert E. 1990. Storyline concerns and word order typology in East and West Africa. Studies in African Linguistics, Supplement 10.

Marchese, Lynell. 1984. Tense innovation in the Kru language family. Studies in African Linguistics 15.189-213.

Moussa-Aghali, Fatimane. 2000. Yarintata [My childhood]. Niamey: Editions Albasa.

Newman, Paul. 2000. The Hausa language: An encyclopedic reference grammar. New Haven: Yale University Press.

Parsons, F. W. 1960. The Verbal system in Hausa: Forms, function and grades. Afrika und Übersee 44.1-36.

Reineke, Brigitte. 1998. Des constructions relatives dans les langues de l'Atakora. Cahiers Voltaïques 3.95-106.

Schubert, Klaus. 1971/72, 1972. Zur Bedeutung und Anwendung der Verbalparadigmen im Hausa und Kanuri. Afrika und Übersee 55.1-49, 208-227, 267-300, and Vol. 56.90-118.

Stassen, Leon. 1997. Intransitive Predication. Oxford: Clarendon Press.

Tuller, Laurice A. 1986. Bijective relations in Universal Grammar and the syntax of Hausa. Unpublished Ph.D. Dissertation, University of California Los Angeles.

Wald, Benji. 1987. Cross-clause relations and temporal sequence in narrative and beyond. Coherence and grounding in discourse: Outcome of a symposium, Eugene, Oregon, June 1984, ed. by Russell S. Tomlin, 481-512. Amsterdam: John Benjamins.

Watters, John. 2000. Syntax. African languages: An introduction, ed. by Bernd Heine and Nurse, Derek, 194-230. Cambridge: Cambridge University Press.

Author's contact information:

Mahamane L. Abdoulaye

BP 5, Niamey, République du Niger, tel. 00227-96972683

mlabdoulaye@gmail.com 